Western University

Scholarship@Western

Centre for the Study of International Economic

Centre for the Study of International Economic

Relations Working Papers

Relations

1984

\title{
Tax Treatment of Housing in a Dynamic Sequenced General Equilibrium Model
}

Bob Hamilton

John Whalley

Follow this and additional works at: https://ir.lib.uwo.ca/economicscsier_wp

Part of the Economics Commons

Citation of this paper:

Hamilton, Bob, John Whalley. "Tax Treatment of Housing in a Dynamic Sequenced General Equilibrium Model." Centre for the Study of International Economic Relations Working Papers, 8425C. London, ON: Department of Economics, University of Western Ontario (1984). 
CENTRE FOR THE STUDY OF INTERNATIONAL ECONOMIC RELATIONS

WORKING PAPER NO. $8425 \mathrm{C}$

TAX TREATMENT OF HOUSING IN A DYNAMIC

SEQQUENCED GENERAL EOUILIBRIUM MODEL

\author{
Bob Hamilton \\ and \\ John Whalley
}

This paper contains preliminary findings from research work still in progress and should not be quoted without prior approval of the author.

DEPARTMENT OF ECONOMICS

THE UNIVERSITY OF WESTERN ONTARIO LONDON, CANADA

N6A 5 C 2

\title{
Depertnent of Ecoromics Library \\ MAY 181984 \\ University of Western Ontario
}


Tax Treatment of Housing in a Dynamic

Sequenced General Equilibrium Model ${ }^{1}$

\author{
Bob Hamilton \\ John Whalley \\ Department of Economics \\ University of Western Ontario \\ London, Ontario \\ CANADA
}

May 1984

$1_{\text {We are grateful to David Sewe } 11 \text { and to seminar groups at }}$ Western Ontario and the Hoover Institution, Stanford University for helpful comments. We wish to acknowledge financial support from SSHRC, Ottawa.

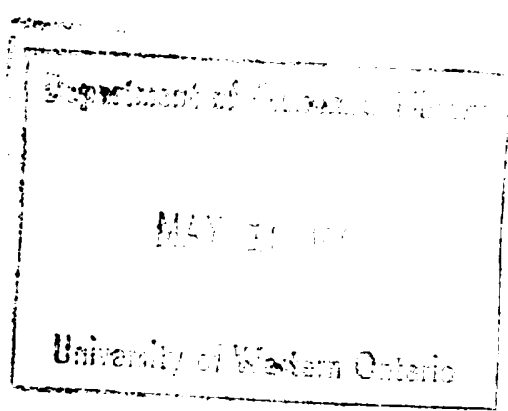


This paper evaluates the efficiency effects of possible changes in the tax treatment of housing using a dynamic sequenced general equilibrium model based on Canadian data for 1972. Our model is similar in structure to that used by Fullerton, Shoven and Whalley (FSW) (1983) to analyze the impacts of a switch to a consumption tax in the US, except that we include two assets rather than one.

The motivation for the paper arises from existing 1iterature on the treatment of housing under the income tax. Most of this literature emphasizes the non-taxation of Imputed income from owner-occupied housing as a deviation from the Haig-Simons concept of Income, and approaches taxation of housing as a static resource allocation issue. This implicitly argues for the inclusion of imputed income in the income tax base and suggests that a welfare gain would result. ${ }^{1}$ When viewed from a dynamic perspective, one's perception of the approprlate tax treatment for housing correspondingly changes. Evaluated relative to a pure consumption tax rather than a pure income tax, housing is appropriately treated at present since the income stream to the asset is not further taxed once the asset has been purchased. The misallocation problem arises not with housing, but from taxation of non-housing capital income.

This issue is, however, more complex than this because of the inter-asset distortion effect arising from the differential tax treatment of housing and non-housing assets. In the presence of taxation of capital income accruing

1 Laidler (1969) estimates the welfare gain for the U.S. from taxing housing imputed income at around one-tenth of one percent of GNP per year. Subsequent calculations have been made by Aaron (1970), Rosen (1979), King (1983), and Henry (1983). 
to non-housing assets, the distortion between housing and non-housing assets may be more or less severe than the intertemporal distortion effect discussed above. Taxing housing imputed income will worsen intertemporal distortions, but will also remove inter-asset distortion effects. A priori, the net effect is unclear.

In using our model to analyze these issues, two main themes emerge. Firstly, full taxation of imputed housing income appears to be a welfare improving change, because the inter-asset distortion from differential tax treatment across assets is more important than the reduction in intertemporal distortions from non-taxation of housing imputed income. This has substantial intuitive appeal since the inter-asset distortion operates on a relatively narrower base than the reduced intertemporal distortion. The Harberger intuition that welfare costs from distortions increase with the square of the tax rate suggests that a higher tax rate applied to a narrow base produces a larger distorting effect than a low tax rate applied to a broader tax base.

Second, moving to either a pure income or a pure consumption tax from existing differential tax treatment across assets in the income tax is a welfare improving change. This is an important result since much of the literature on the income-consumption tax question treats existing income tax systems as part way towards a consumption tax. A suggestion often made is that a significant portion of the potential gains from moving to a consumption tax will have already been achieved under existing tax treatment because of the tax treatment of housing, pensions and other tax preferred investment vehicles. Our results 
suggest the opposite, namely that the varlance in tax rates acros different savings vehicles produces inter-asset distortions which are more important than intertemporal distortions in the tax system. In our calculations, removing these by moving to either a pure income or pure consumption tax is a welfare improving change. Finally, a note of caution is in order. The numerical results we report, while based on a model incorporating two assets rather than one as in earlier dynamic sequencing literature, do not capture anything approaching the full range of tax rates across savings vehicles which in practice characterize modern tax systems. We do not incorporate debt issuance (and mortgage deductibility as a tax issue), renting versus home ownership, and a range of other issues which a more complete but more complex (and more costly) model should encompass. What we emphasize are the broad themes and insights from our model which are suggestive of directions to take in approaching alternative tax reform options. The strength of the effects may well change in a more complex model, but we believe the underlying themes we emphasize will remain.

\section{THE DYNAMIC SEQUENCED EQUILIBRIUM APPROACH}

We use a two-asset dynamic sequenced general equilibrium model whose main feature is the sequencing of single period equilibria in which all markets clear both for consumption and capital goods. The sequencing occurs through savings decisions which change the capital stock of the economy over time. 
In each period both demand and production occur, which are affected by tax rate parameters. The initial year equilibrium is assumed to 11 e on a balanced growth path if there are no changes in tax policies. If changes in taxes occur, the economy is displaced from its initial balanced growth path, and after a transitional period (involving several single period equilibria) settles on a new balanced growth path. Evaluation of the welfare effects of the policy change is then based on a pairwise comparison of the consumption paths under the unchanged and changed policy regimes.

In the model savings in any period reflect utility maximization over both current and expected future incremental consumption from savings, and infinitely lived consumers are assumed (i.e., no life-cycle structure enters the model). Savers acquire capital goods in the current period which yield a capital service stream (and thus an income stream) in all future periods. The capital service endowment in any period thus reflects previous periods savings. Savings depend on the expected rental price of capital in future periods, with myopic expectations assumed. In the counterfactual analyses performed with the model the approach to a new balance growth path is relatively smooth and using a perfect foresight assumption would not significantly affect results (see Ballard and Goulder (1983)).

The key feature which differentiates this approach from other numerical general equilibrium tax models, such as Harberger (1962) or Shoven and Whalley (1972), is the presence of intertemporal utility maximization and the sequencing of the economy over time through capital accumulation. The analytics of this can be seen most simply in the two-commodity case which involves a single consumption and a single capital good in each period. In this, consumers are assumed to maximize a utility function in each period subject to their current period budget constraint, i.e., 
(1)

$$
\begin{aligned}
& \max U\left(C_{0}, C_{F}\right) \\
& \text { s.t.o. } I=p_{c} C_{0}+p_{s} s
\end{aligned}
$$

where

$C_{0}=$ consumption in period 0 $C_{F}=$ the expected increment to consumption in all future periods from

$S$ = quantity of the capital good bought in period 0

$\mathrm{p}_{\mathrm{S}}=$ price of the capital good in period 0

$\mathrm{P}_{\mathrm{C}}=$ price of the consumption good in period 0

$I$ = current period income.

In order to link the expected consumption stream in the preferences to the amount of capital goods acquired today, some form of expectations hypothesis must be used. Under an assumption of myopic expectations

$$
P_{C} C_{F}=P_{K}^{\gamma S}
$$

where

$\gamma=$ rate of return on capital goods (net of depreclation) in all future periods in terms of capital service units per period.

and

$\mathrm{P}_{\mathrm{K}}=$ current period rental price of capital.

Thus, a unit of capital goods acquired today is expected to increase the saver's capital service flow endownent (net of depreciation) in all future periods. In each future period this increment is expected to sell for a price $P_{K}$ per service unit, giving additional income in all future periods from capital goods acquired today of $\mathrm{P}_{\mathrm{K}} \gamma \mathrm{S}$. Savings is thus treated as the purchase of a perpetual annuity, with the expected income stream from the annuity varying with the current period rental price of capital. 
Substituting from (2) into the budget constraint in (1) gives

(3)

$$
\begin{aligned}
& \max U\left(C_{0}, C_{F}\right) \\
& \text { sto } I=p_{c} C_{0}+\frac{p_{s} p_{c}}{p_{k} \gamma} \cdot C_{F}
\end{aligned}
$$

and the budget constraint in (3) can be rewritten as

$$
I=P_{0} C_{0}+P_{C}^{F} C_{F}
$$

where $\quad \mathrm{P}_{C}^{\mathrm{F}}=\frac{\mathrm{P}_{S} \mathrm{P}_{C}}{\mathrm{P}_{\mathrm{K}} \gamma}$

$\mathrm{P}_{\mathrm{C}}^{F}$ represents the current period price of an annuity expected to yield one unit of future consumption in all future periods. A reduction in the current period rental price of capital will increase the price of future consumption. Through the substitution effect this will reduce the amount of incremental future consumption desired. If the reduction in the price of future consumption is larger than the reduction in the rental price of capital, savings will fall. This, in turn, implies a positive elasticity of savings with respect to the rate of return on capital. 1

${ }^{1}$ As a rough approximation the elasticity substitution in preferences' is equal to one plus the elasticity of savings with respect to the real net of tax rate of return (see Feldstein (1978)). Defining the future consumption stream from savings as

$$
C_{F}=\mathbf{r} \cdot \hat{s}
$$

where

$$
\begin{aligned}
& \hat{s}=\text { financial savings }\left(P_{S} \cdot S \text {, above }\right) \text {, and } \\
& r=\text { own rate of return on savings }\left(\frac{P_{K} \gamma}{P_{S}} \text {, above }\right)
\end{aligned}
$$

yields

$$
\frac{\partial C_{F}}{\partial \mathbf{r}}=\hat{\mathbf{s}}+\mathbf{r} \cdot \frac{\partial \hat{\mathbf{S}}}{\partial \mathbf{r}}
$$

Thus

$$
\frac{1}{\hat{S}} \frac{\partial C_{F}}{\partial r}=1+\frac{r}{\hat{S}} \cdot \frac{\partial \hat{S}}{\partial r} \text { or } \frac{r}{C_{F}} \cdot \frac{\partial C_{F}}{\partial r}=1+\frac{r}{\hat{S}} \cdot \frac{\partial \hat{S}}{\partial r}
$$


The model is completed by a production side based on production functions and a specification of tax policies. A change in tax treatment of capital income changes the net of tax factor income return to savers and thus consumers saving behavior. In the first period, the production of consumption and capital goods will change. The change in savings means that in subsequent periods the time path of the economy, represented through the sequence of single period equilibria, will be altered.

In making welfare evaluations of the impacts of a tax policy change, instantaneous utility is used in calculating Hicksian EVs and CVs in each period. This corresponds to the treatment commonly employed in other intertemporal models of using an additively separable intertemporal utility function. If total utility were used at each point in the sequence of equilibria, double-counting would occur since utility from deferred consumption would appear twice, once through expected utility when savings were made, and once as utility from consumption at the time it occurs.

\section{DYNAMIC SEQUENCING IN THE TWO-ASSET CASE}

The model we use to analyze changes in the tax treatment of housing, is of smaller commodity dimension than the FSW model of the U.S. and is limited to one household, but departs from this earlier model by incorporating two assets rather than one. The reasons for using a two asset formulation lie in the tax issues under investigation. Since we wish to analyze the effects of possible changes in the tax treatment of housing two separate savings assets are needed, each of which provides a different factor service flow for the production side of the model. Housing capital services are a factor input to housing service consumption, while non-housing capital services are a factor input in other consumption good and capital good industries. 
Since saving of each asset reflects utility maximization, incremental future consumption is a vector, and to obtain the income tax preference from purchase of housing services requires that the housing rather than the non-housing asset must be bought. Housing rather than non-housing consumption services appear as the incremental future consumption stream from the tax preferred asset.

This two-asset structure is reflected in the nesting hierarchy used in preferences in the model outlined in Figure 1. Substitution occurs first between current and future consumption as in the previous section, but these are now composites reflecting the various types of consumption. At level 2 the housing and non-housing consumption choice is made in each period, at level 3 leisure and non-leisure substitution occurs in period 0 , and level 4 specifies substitution between non-leisure goods in period 0 . To simplify the model no intertemporal labour supply behavior is incorporated, but extensions of the modelling approach in these directions would be possible. Level 1 elasticities determine the elasticity of savings with respect to the real net of tax rate of return, while level 2 elasticities determine the elasticity of substitution between housing and non-housing goods, and thus the price elasticity of demand for housing. These are key elasticities for the results which follow and their values are discussed later.

An innovation in our two-asset model beyond what was done in FSW are the changes which must be made to the benchmark equilibrium data set for dynamic consistency. This significantly complicates the implementation of the dynamic sequenced approach relative to the one-asset case. 


\section{Figure 1}

Nesting Structure in Preferences Used in the Model

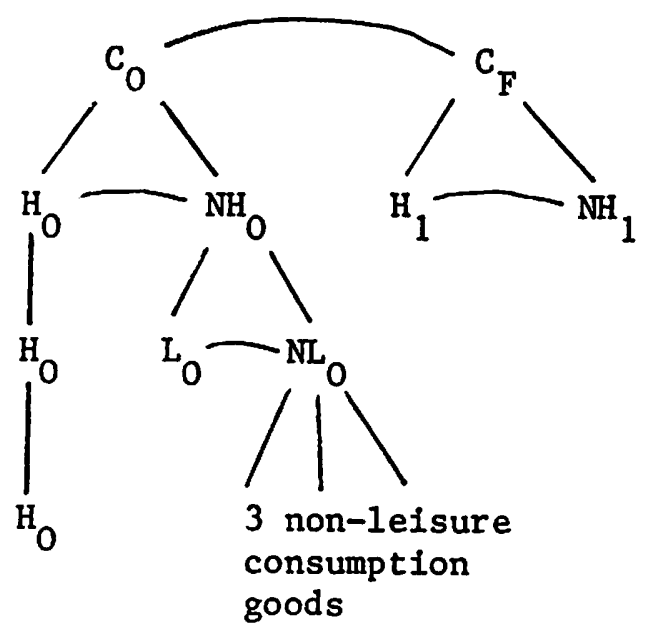

Level 1 (intertemporal consumption)

Level 2 (housing/non-housing choice in each perfod)

Leve1 3 (leisure/non-1elsure consumption choice in period 0 )

Level 4 (substitution between non-leisure goods in period 0) 


\section{Figure 2}

Main Features of Static Benchmarking in the One-Asset Case for a Simple One-Consumer, No-Tax, Closed Economy (with Projection to Balanced Growth).

Industries

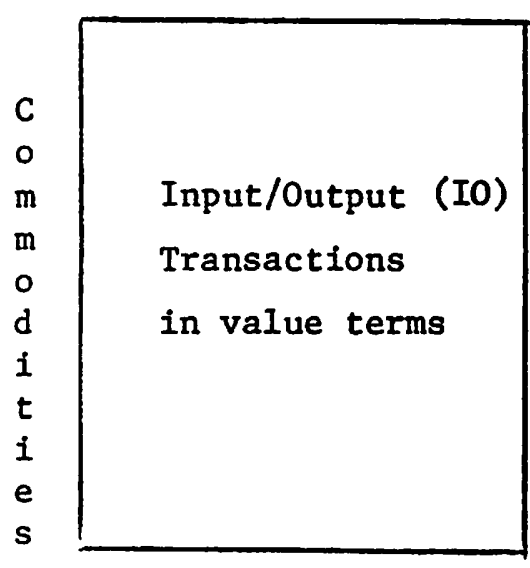

Value added in value terms (VA)
Main Features

(1) Units convention used to separate the price and quantity observations in the benchmark data which is constructed in value terms.

(2) Budget balance ( $\Sigma F D=\Sigma V A$ ) required for Walras Law.

(3) Demand - Supply equalities for commodities, $\left(F D_{i}+\sum_{j} I O_{i j}=V A_{i}+\sum_{j} I O_{j i}\right.$ for all 1.)

(4) Benchmark conditions met by constructing value added and final demands as consistent marginal conditions and applying RAS $^{1}$ consistency method.

${ }^{1}$ See Bacharach (1970). 
The main features of static benchmarking (with a projection to a balanced growth path) are outlined in Figure 2 for a simple oneconsumer elosed economy. ${ }^{1}$ In the no-tax case this involves transactions data for which demands equal supply, and zero profit conditions hold. This is met by having the sum of value added equal the sum of the final demands in value terms. The projection to a balanced growth path is straightforward since $n$, the population growth rate, must equal $\frac{\dot{K}}{K}=\frac{\gamma S}{K}$. Thus, given a value of $\gamma$ and a single period equilibrium data set, a population growth rate can be calculated to produce a micro consistent benchmark equilibrium balanced growth path.

In the two-asset case, implementing this procedure is more complex. If we assume homothetic preferences and balanced growth, relative prices cannot change between periods in the no-policy change equilibrium sequence, and more conditions are required for dynamic consistency in the two-asset case than with a one-asset benchmark data set.

Using the notation $\mathrm{H}$ and $\mathrm{NH}$ to refer to housing and non-housing consumption goods $(\mathrm{H}, \mathrm{NH})$, capital goods $\left(\mathrm{S}_{\mathrm{H}}, \mathrm{S}_{\mathrm{NH}}\right)$, capital service endowments $\left(\mathrm{K}_{\mathrm{H}}, \mathrm{K}_{\mathrm{NH}}\right)$, per period service flow returns from assets $\left(\gamma_{\mathrm{H}}, \gamma_{\mathrm{NH}}\right)$, asset rental prices $\left(\mathrm{P}_{\mathrm{K}}^{\mathrm{H}}, \mathrm{P}_{\mathrm{K}}^{\mathrm{NH}}\right)$, capital goods prices $\left(\mathrm{P}_{\mathrm{S}}^{\mathrm{H}}, \mathrm{P}_{\mathrm{S}}^{\mathrm{NH}}\right)$, and consumption good prices $\left(\mathrm{P}_{\mathrm{C}}^{\mathrm{H}}, \mathrm{P}_{\mathrm{C}}^{\mathrm{NH}}\right)$, these conditions are:

${ }^{1}$ See also St Hilaire and Whalley (1983), and Mansur and Whalley (1984). 
(8) Balanced growth $n=\frac{\gamma_{\mathrm{H}} \mathrm{S}_{\mathrm{H}}}{\mathrm{K}_{\mathrm{H}}}=\gamma_{\mathrm{NH}} \frac{\mathrm{s}_{\mathrm{NH}}}{\mathrm{K}_{\mathrm{HN}}}$

(9) $\begin{aligned} & \text { The price ratio } \\ & \text { between expected } \\ & \text { future housing and. } \\ & \text { non-housing con- }\end{aligned}$
$\mathrm{P}_{\mathrm{C}}^{\mathrm{NH}}$$\quad \frac{\mathrm{P}_{\mathrm{C}}^{\mathrm{H}}}{\mathrm{P}_{\mathrm{K}}^{\mathrm{H}} \gamma_{\mathrm{H}}} \cdot \frac{\mathrm{P}_{\mathrm{K}}^{\mathrm{H}} \mathrm{P}_{\mathrm{H}}^{\mathrm{H}}}{\mathrm{P}_{\mathrm{S}}^{\mathrm{NH}} \cdot \mathrm{P}_{\mathrm{C}}^{\mathrm{NH}}}$ sunption equals the current period price ratio

(10) The ratdo of $\mathrm{H}$ to $\mathrm{NH}$ consumption in the current period equals the $\frac{\mathrm{H}_{\mathrm{O}}}{\mathrm{NH}_{\mathrm{O}}}=\frac{\mathrm{H}_{\mathrm{F}}}{\mathrm{NH}_{\mathrm{F}}}=\frac{\mathrm{P}_{\mathrm{K}}^{\mathrm{H}} \gamma_{\mathrm{H}}}{\mathrm{P}_{\mathrm{C}}^{\mathrm{H}}} \cdot \frac{\mathrm{P}_{\mathrm{C}}^{\mathrm{NH}}}{\mathrm{P}_{\mathrm{K}}^{\mathrm{NH}} \gamma_{\mathrm{NH}}} \cdot \frac{\mathrm{S}_{\mathrm{H}}}{\mathrm{S}_{\mathrm{NH}}}$ ratio of $\mathrm{H}$ to $\mathrm{NH}$ consumption expected in future periods.

(11) Boundedness of the
present value of consumption (marginal rate of time preference

$>\mathrm{n}$ )

If the units convention that all prices equal 1 in the initial period equilibrium commonly adopted in static benchmarking is used (see Mansur and Whalley (1984)), in the no-tax case the above conditions imply that from (9) $\quad \gamma_{\mathrm{H}}=\gamma_{\mathrm{NH}}$

from (8) $\quad \mathrm{S}_{\mathrm{H}} / \mathrm{K}_{\mathrm{H}}=\mathrm{S}_{\mathrm{NH}} / \mathrm{K}_{\mathrm{NH}}$

from (10) $\quad \mathrm{S}_{\mathrm{H}} / \mathrm{H}=\mathrm{S}_{\mathrm{NH}} / \mathrm{NH}$

and from (11): $\mathrm{S}_{\mathrm{H}}<\mathrm{K}_{\mathrm{H}}, \mathrm{S}_{\mathrm{NH}}<\mathrm{K}_{\mathrm{NH}}$.

A schematic representation of a dynamically consistent benchmark equilibrium data set meeting these conditions is displayed in Figure 3. Compared to the no-tax case these additional conditions imply a set of restrictions on the marginal conditions (represented by final demands 
Figure 3

Dynamic Consistency in a Two-Asset (Housing (H), Non-Housing (NH)) Benchmark Equilibrium Data Set for a One-Consumer, No-Tax, Closed Economy

Industries

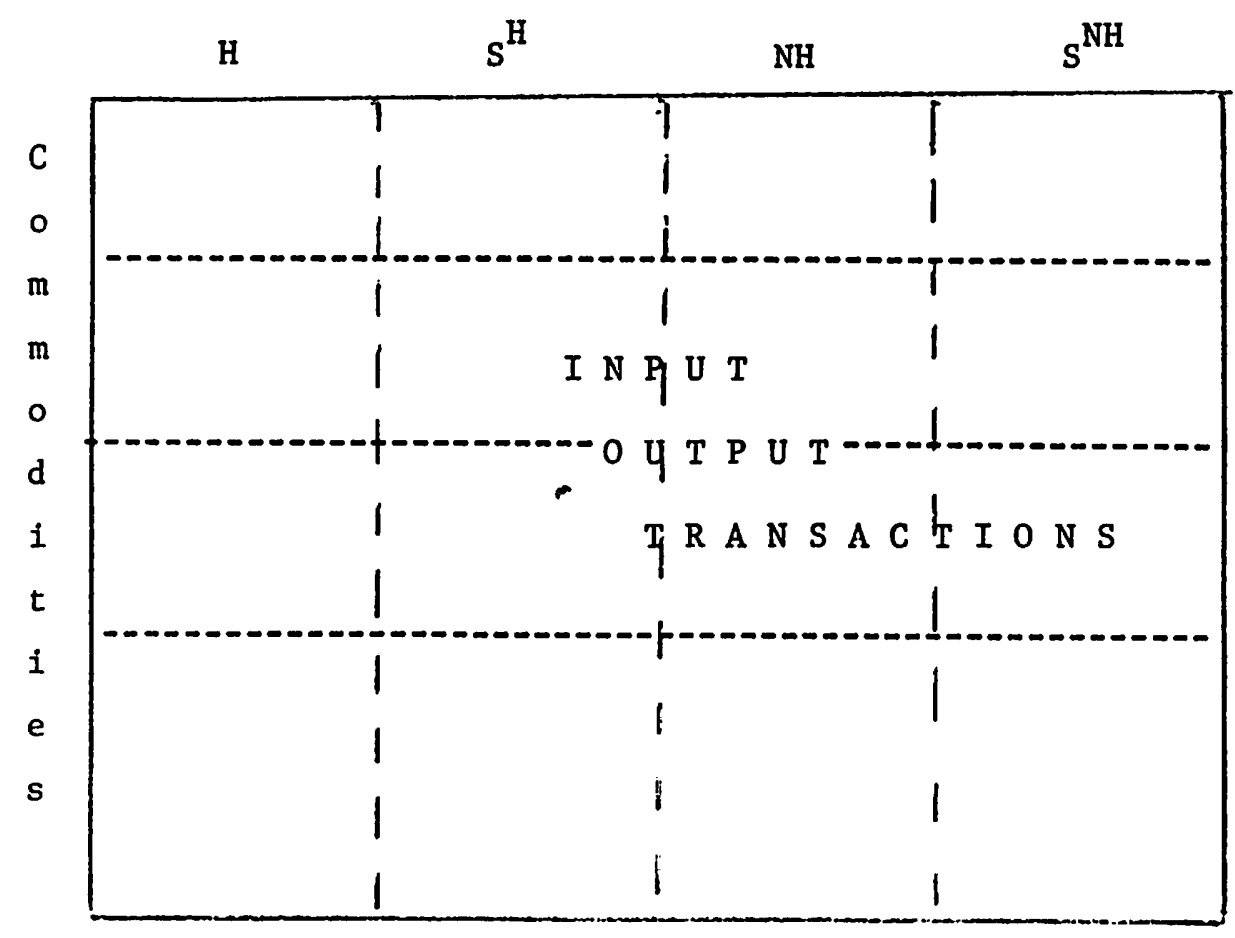

Value Added (VA)

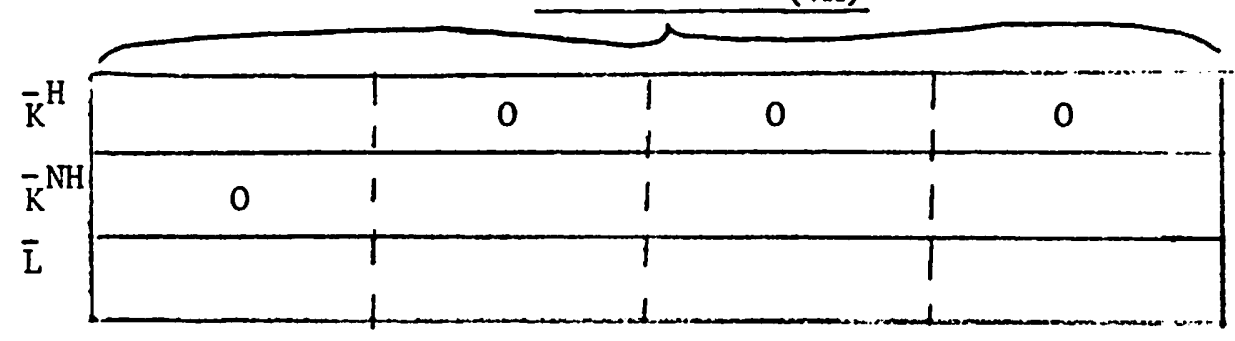

Final Demands (FD)

FD

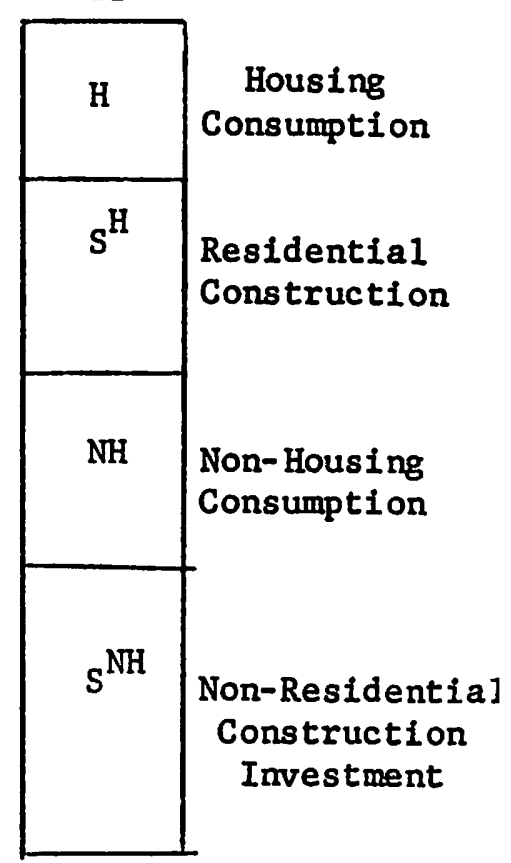

Additional Conditions. Beyond Conventional Benchmark Equilibrium Restrictions

$$
\begin{aligned}
\therefore \quad & \mathrm{s}_{\mathrm{H}} / \mathrm{H}=\mathrm{s}_{\mathrm{NH}} / \mathrm{NH} \\
& \mathrm{s}_{\mathrm{K}} / \overline{\mathrm{K}}_{\mathrm{H}}=\mathrm{s}_{\mathrm{NH}} / \overline{\mathrm{K}}_{\mathrm{NH}} \\
& \mathrm{s}_{\mathrm{K}}<\overline{\mathrm{K}}_{\mathrm{H}} 1, \mathrm{~s}_{\mathrm{NH}}<\overline{\mathrm{K}}_{\mathrm{NH}} 1
\end{aligned}
$$

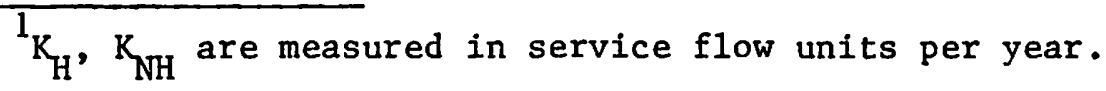


and value added data) before the micro-consistent benchmark data are generated using the RAS procedure on the intermediate transactions accounts. With the approprlate modifications required to incorporate taxes, these conditions are satisfied in the micro-consistent data set for Canada used here to analyze changes in the tax treatment of housing.

A further important property of the model is that if the elasticity of substitution at level 2 is less than unity, the model is dynamically unstable and cannot converge to a new balanced growth path. In the event of an increase in the consumer price of housing services, such as would follow from taxing housing imputed income, the adjustment required from the substitution effect against housing is for housing consumption to fall. Because the incremental future housing consumption stream is determined from additions to the housein capital stoc, $\mathrm{s}^{\mathrm{H}}=\frac{\mathrm{P}_{\mathrm{C}}^{\mathrm{H}}}{\mathrm{P}_{\mathrm{K}}^{\mathrm{H}}}$, and

$$
\frac{\delta \mathrm{S}^{\mathrm{H}}}{\delta \mathrm{P}_{\mathrm{c}}^{\mathrm{H}}} \cdot \frac{\mathrm{P}_{\mathrm{c}}^{\mathrm{H}}}{\mathrm{S}^{\mathrm{H}}}=1+\frac{\mathrm{P}_{\mathrm{c}}^{\mathrm{H}}}{\mathrm{H}} \cdot \frac{\delta \mathrm{H}}{\delta \mathrm{P}_{\mathrm{H}}^{\mathrm{c}}}
$$

Thus, the elasticity of residential construction demand with respect to the price of housing services is equal to one plus the elasticity of current housing consumption with respect to the price of housing consumption. If the elasticity at level 2 in the preferences is less than unity, the quantity response for $\mathrm{S}_{\mathrm{H}}$ is opposite to the quantity of response of $\mathrm{H}$ itself, producing dynamic behaviour inconsistent with stability. A second level elasticity of less than one (from (12)) implies a negative price elasticity of residential housing demand. The 
literature values on which we base the elasticity specification in the model, imply a second level elasticity value of 1.5 (discussed below), and thus this problem does not arise with our model specification but should be noted nonetheless.

IV A TWO-ASSET DYNAMIC SEQUENCED MODEL FOR CANADA

In this section we outline the main features of our two-asset dynamic sequenced general equilibrium model for Canada. The model incorporates two capital good industries--housing and non-housing; four consumption good industries--manufacturing, non-manufacturing, housing, and services--a total of six industries. Three factors of production are incorporated--non-housing capital services, housing capital services, and labour services. The model is benchmarked to dynamically consistent equilibrium data, based on aggregated data drawn from the 1972 microconsistent tax policy Canadian data set constructed by St. Hilaire and Whalley (1983). A projection of these data to an initial balanced growth equilibrium sequence uses the procedures outlined above to ensure dynamic consistency of the data set.

The model incorporates CES value-added functions for each industry, with intermediate production in the form of fixed input-output coefficients. The industry providing housing consumption services uses housing capital services and labour services as inputs. Other industries use non-housing capital services and labour services as inputs. Labour and non-housing capital services are assumed to be intersectorally mobile in each period but internationally immobile. In any period the capital service endowment of each type is given by applying the flow rate of return assumed to the stock of the asset. Savings of either type of asset add to the asset stock. 
CES final demand functions are used which incorporate the four levels of nesting described earlier. The foreign trade specification involves constant elasticity excess demand functions which Canada faces (export demands and import supplies by foreigners, consistent with trade balance). The model thus uses homogeneous products, and does not follow the Armington assumption common in other applied general equilibrium models (see Shoven and Whalley (1984)). All major taxes operating in Canada in 1972 (income, sales and excise, property, corporate, and social security taxes) appear in the model in ad valorem equivalent form. To analyze tax policy changes an equal tax yield requirement is adopted. Revenues collected in the corresponding base sequence equilibrium are preserved in real terms by an additional uniform rate tax or subsidy on all non-leisure consumption goods. In the one-consumer version of the model used here, the 12 income ranges appearing in the 1972 Canadian data due to St Hilaire and Whalley are aggregated into one. Non-housing capital income is thus taxable to the single consumer assumed at the average marginal personal tax rate.

The elasticity configuration used in final demands involves four sets of substitution parameters, with the elasticities at Level 1, 2, 3 , and 4 set at $1.4,1.5,0.5$, and 1.0 respectively. The top level elasticity corresponds approximately to a savings elasticity of 0.4 (Boskin (1978)). The second level value implies a price elasticity of demand for residential construction of approximately .5 (see summary of literature estimates in Piggott and Whalley (forthcoming)). Given the share of 'expanded' Income spent on leisure in the benchmark data, the third level value of 0.5 corresponds to an uncompensated labour supply elasticity of approximately .15 (Lewis (1975)). The final level provides 
for Cobb-Doug las substitution between non-leisure, non-housing consumption commodities. Elasticities of substitution in value-added functions are based on Caddy (1976).

In using the model to analyze tax changes, a comparison is made between the initial balanced growth path equilibrium sequence and each new sequence of equilibria generated by the model for the policy change considered. A 200-year period is examined, with an interpolation made between years for which equilibria are computed in order to reduce execution costs. One equilibrium per year is computed for the first 10 years, each second year for the next 20 years, one every 5 years for the next 70 years, and one each 10 years for the remaining 100 years. A termination term is used in the welfare comparisons across the sequences of equilibria.

Convergence to a new balanced growth path for the policy changes analyzed here usually occurs (within a narrow tolerance) within 100 years. While this may seem a lengthy time period, it is consistent with the large adjustment times found elsewhere in the growth literature (see Sato (1963), and Fullerton, Shoven and Whalley (1983)). Not surprisingly, the housing capital stock is the slowest factor to adjust to its new long-run equilibrium value consistent with a completed transition between balanced growth paths.

\section{RESULTS}

The model has been used for a range of policy change experiments, involving full taxation of housing imputed income and other changes in the tax system. The latter include the abolition of property taxes, fully taxing real capital gains on housing, and a switch to a pure consumption tax. 
In these experiments the new sequence of equilibria has been computed, along which the economy approaches a new balanced growth path under the changed policy regime. By comparing equilibria pairwise between the old and new sequences, the welfare change period by period is calculated in terms of Hicksian compensating and equivalent variations. For equivalent variations, the calculation uses base case prices along the original sequence of equilibria; for compensating variations the revised case prices are used. The discounted present values of the stream of (price adjusted) EVs and CVs are then calculated. To allow for easier comparisons between results from the various experiments, these welfare measures are all reported as a percentage of the discounted present value of the economy's income stream.

In addition to calculating these economy-wide welfare measures, the welfare impact of each policy change on the initial population only has been calculated (i.e., those alive in the initial period). Further summary statistics, such as the change in the ratio of the housing to non-housing capital stocks between the balanced growth paths, and changes in the rental price of housing and non-housing assets between the balanced growth paths are also calculated.

In Table 1, results are reported for an experiment where imputed housing income is fully taxed at the marginal tax rate applying to other capital income in the base period equilibrium. A welfare gain of approximately one third of one percent of the discounted present value of the economy's income stream results, suggesting that the inter-asset distortion effects of the income tax are more severe than the intertemporal distortion reducing features of the non-taxation of imputed income. Intertemporally, there is a welfare loss from taxing housing 
imputed income, but the welfare gain from reducing inter-asset distortions is larger, resulting in a net welfare gain. With a correction to account only for the initial population, the welfare gain is somewhat smaller. The initial period equivalent variation being positive is consistent with the result that taxing imputed income to housing reduces savings.

The fact that the inter-asset welfare improvement outweighs the intertemporal welfare loss in Table 1 should not surprise those familiar with approximation measures of welfare costs of taxes. The simple calculation of the welfare cost of a tax using a Harberger approximation approach involves a tax rate squared term. The inter-asset distortion from the lack of taxation of imputed income operates with a higher tax rate on a narrower tax base than the offset to intertemporal tax distortions. The gain from removing the distortion on a narrower tax base (the interasset distortion) more than outweighs the loss from worsening the distortion on the wider tax base (the intertemporal distortion).

An Implication which follows from the welfare gain from full taxation of imputed housing income in Table 1 is that, despite worsening intertemporal distortions in the tax system, moving from the present income tax to a pure income tax yields a welfare improvement. This result contrasts with recent tax literature which has focussed on the potential welfare gains from moving to a pure consumption tax, while simultaneously characterizing the current income tax as part way between an income and consumption tax. Often it is claimed that the potential gains from a move to a pure consumption tax are small because the current tax system is already a partial consumption tax. However, results in Table 1 suggest that the inter-asset distortions in the tax system may be more severe than the intertemporal distortions, and moving to either a pure income or pure consumption tax could well dominate current arrangements. 


\section{Table 1}

Welfare and Other Impacts From Fully Taxing

Imputed Housing Income at Marginal Tax

Rate Applying to Other Capital Income

(Central Case Specification)

(1) DPV of EV's as \%

of DPV of economy's income

stream (base case prices)

(2) DPV of CV's as \% of DPV

of economy's income

stream (revise case prices)

(3) (1) corrected to represent impact only on initial

population in period 0

(4) (2) corrected to represent impact only on initial

population in period 0

(5) Change in $\mathrm{K}_{\mathrm{H}} / \mathrm{K}_{\mathrm{NH}}$ ratio

between balanced growth

paths

$-.008$

(6) Change in gross of personal tax rental price of housing services between balanced growth paths

(7) Change in gross of personal tax rental price of nonhousing services between balanced growth paths

(8) Initial period EV in \$mil

1972 (\% of 1972 consumption in parentheses) 
In Table 2, the results of further tax experiments are reported; for ease of comparison, Column 1 repeats the results from Table 1.

Column 2 reports the impacts of fully taxing housing income at the marginal tax rate on labour income. Since a higher marginal subsidy rate on housing income is involved in both the base case and in the revised case, under this model specification the welfare gain from taxing imputed income increases substantially.

Column 3 reports the impacts of abolishing the property tax. In this case a welfare loss results because the property tax partially offsets the inter-asset distortion effects of the income tax since homeownership also involves a tax on factor income. This welfare loss is associated with a negative equivalent variation in the initial period since savings increase under this policy change. Column 4 reports the impacts of fully taxing real capital gains on housing. A significant portion of the potential welfare gain from fully taxing housing income accrues in this case.

Finally, Column 5 reports the impacts of a switch to a pure consumption tax in this two-asset rather than one-asset model. A 1arger welfare gain is obtained in the case of fully taxing housing income at the marginal tax rate on other capital income. Column 5 and columns 1 and 2 therefore suggest that a move to either a pure income or a pure consumption tax from the present differential tax treatment across assets is welfare improving .

In Table 3 the impacts of full taxation of housing imputed income are analyzed under alternative model specifications. The interesting feature here is that by excluding various features of the model, the calculated welfare gain as a fraction of the discounted present value 
ڤิ) 
of the economy's income stream increases. Excluding the labour-leisure choice, or excluding factor taxes from both the original data set and the two equilibrium sequences, results in a larger welfare gain from taxing housing Imputed income than is true for the central case model specification. This gain is even larger if both the labour leisure choice and the factor taxation system are removed together from both the model and data.

These results provide indications as to how the interaction of the various elements of the model affect the welfare impacts of tax changes. While the emphasis thus far has been on the intertemporal and inter-asset tax distortions which occur under non-taxation of housing imputed income, tax distortions affecting the lower levels of the nesting hierarchy in preferences can also influence model results. Below the housing level, distortions occur between components of non-leisure goods. The labour-leisure choice is incorporated in a similar way to that outlined in Shoven and Whalley (1972), by expanding the labour endowment of the economy with a portion of leisure repurchased. Leisure itself is a relatively undistorted component of total expenditure, and excluding the labour-leisure choice both reduces aggregate income and results in proportionally more income being channelled through a more severely tax distorted sequence of transactions. Excluding the labour-leisure choice increases the measured welfare gain when calculated as a percentage of the discounted present value of the economy's income stream. Equally, excluding factor taxes from both the model and data has a similar effect. A result of taxing housing imputed income is to divert consumption from housing to non-housing expenditure categories. 
$\underline{\text { Table } 3}$

Impacts of Full Taxation of Housing Imputed Income

Under Alternative Model Specifications

(1)

(2)

(3)

(4)

$\begin{array}{ll}\text { Central } & \text { Excluding } \\ \text { Case } & \text { Labour/Leisure } \\ & \text { Cholce }\end{array}$

Excluding

Factor Taxes

From Model

.304

.365

.368

.452

economy's income stream

(base case prices)

2) DPV of CV's as \% of DPV of economy's income

stream (revise case prices)

.309

.374

.381

.471

3) (1) corrected to represent impact only on initial population in period 0

4) (2) corrected to represent impact only on initial

population in period 0

5) Change in $\mathrm{K}_{\mathrm{H}} / \mathrm{K}_{\mathrm{NH}}$ ratio between balanced growth paths

$$
-.008-.009
$$

6) Change in gross of personal tax rental price of housing services between balanced growth path $-.093-.092$ $-.094$

7) Change in gross of personal tax rental price of nonhousing services between balanced growth paths $.058 \quad .059$ .061 .061

3) Initial period EV in $\$$ mill 1972 (\% of 1972 consumption in parentheses)

$\begin{array}{rr}570.37 & 574.4 \\ (.57) & (.67)\end{array}$

582.92

(.64)

555.7

(.77) 
Expenditures on non-housing consumption goods are themselves distorted indirectly through the factor tax system, and excluding factor taxes from the model means that the measured welfare gain from taxing housing Imputed income correspondingly increases. Excluding both the labourleisure choice and factor taxes fromithe model increases the estimated gain even more. Thus, while the estimates reported in Table 1 for the effects of taxing imputed housing income may have strong intuitive appeal, the quantitative orders of magnitude involved are clearly dependent upon the tax and other parameters used in the rest of the model.

In Table 4, the sensitivity of results in Table 1 is further explored by considering cases where the substitution elasticity between housing and nonhousing consumption goods is increased to 3.0 from the central case value of 1.5. The interesting feature here is that when the model is used with this higher elasticity the computed welfare gain falls. At first sight this result is counter-intuitive since a simple consideration of a Harberger triangle calculation would suggest that for the inter-asset distortion, the gain from its removal should be Iinear in the demand elasticity; i.e., the net gain should rise with this elasticity. However, this intuition is misleading since the effect of removing the tax distortion is to divert expenditures from housing to non-housing consumption. Choices between non-housing consumption goods are themselves severely distorted through the labour-leisure choice, the factor tax system, and other taxes. Increasing the elasticity of substitution between housing and non-housing consumption categories increases the substitution effect and lowers the measured welfare gain. 


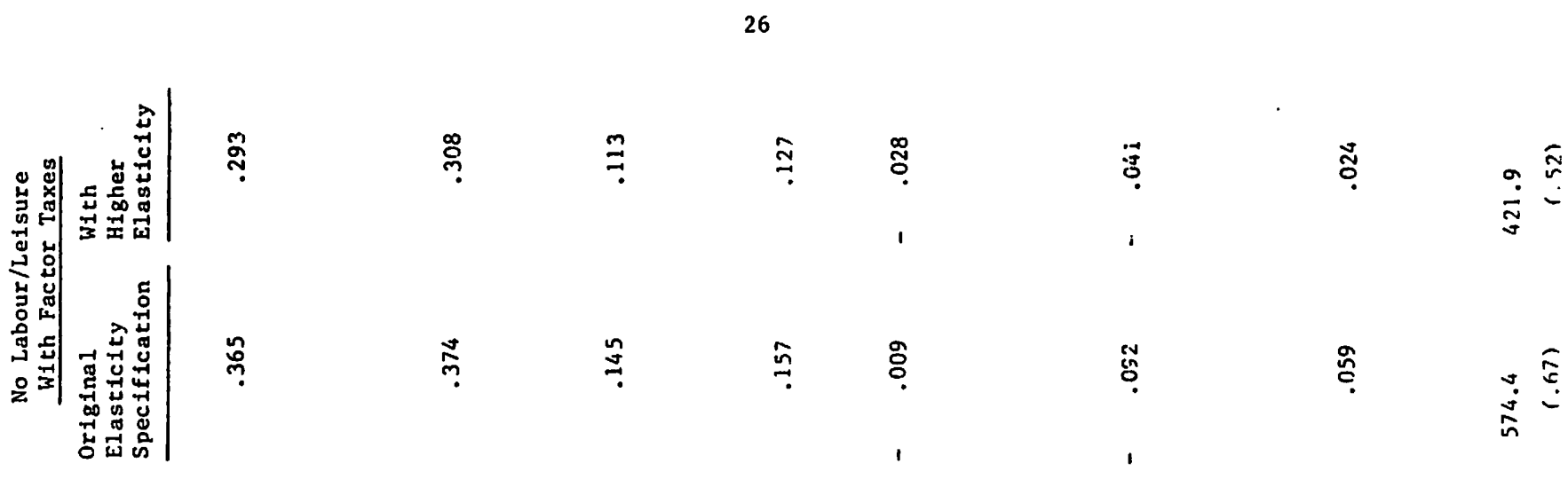

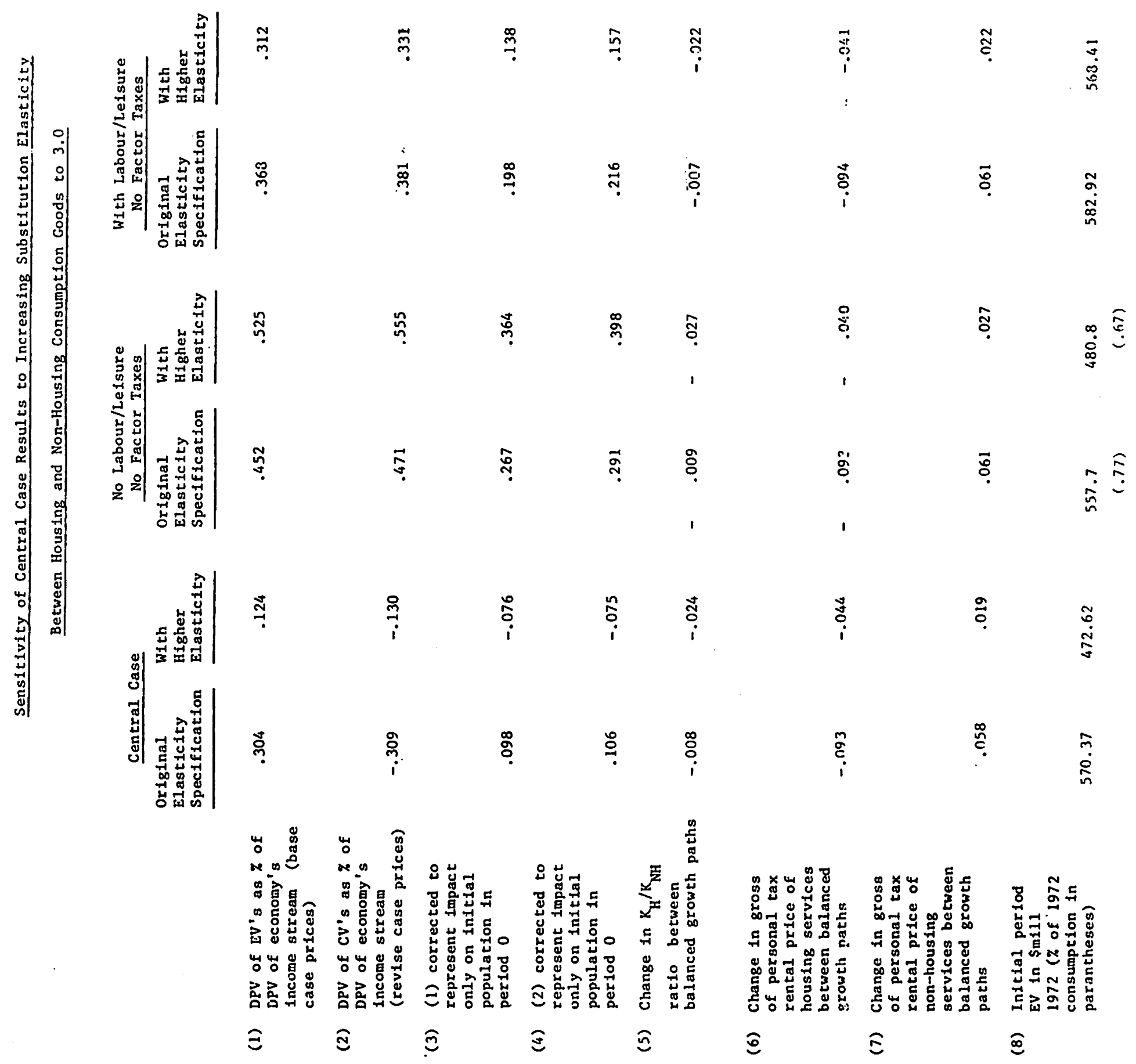


When the model variant with no labour-leisure choice and the absence of factor taxes is ased, the higher elasticity case yields a larger welfare gain under full taxation of housing. Alternatively, when the model is used with a labour-leisure choice but without any factor taxes, or with no labour-leisure choice but with factor taxes, a smaller welfare gain is associated with a higher elasticity variant because of the distorting effects at the third and fourth levels of the nesting structure. While other sensitivity analyses with the model are clearly possible, these results suggest that the further distorting effects involving the third and fourth layers of the substitution hierarchy in the preferences can exert a significant influence on results. VI CONCLUSIONS

This paper reports results from a dynamic sequenced general equilibrium model for Canada based on 1972 data analyzing the impacts of possible changes in the tax treatment of housing. The model differs from earlier dynamic sequenced equilibrium tax models (such as Fullerton, Shoven and Whalley (1983)) in using a two-asset rather than a one-asset formulation structure. This involves significant modifications to the basic approach, espectally in the dynamic benchmarking procedures employed.

The paper stresses how in existing literature discussion of tax treatment of housing, housing is usually cited as one of the major sources of income tax base erosion, since imputed income from housing is not fully taxed. Previous work on this issue has typically computed the welfare gains from including housing 
imputed income in the tax base. The present paper departs from existing literature in noting that from a consumption tax point of view the tax treatment of housing is appropriate, and the problem arises with double taxation of non-housing assets. Evaluating reform options towards tax treatment of housing thus involves analyzing the relative size of the intertemporal and inter-asset distortion effects associated with alternative housing taxation regimes.

Results indicate that taxing imputed housing income is a welfare improving change because the removal of the inter-asset distortion effect of present tax treatment outweighs the gain from improved intertemporal consumption allocation. These results have the further implication that the most important issue in the tax treatment of capital income could well be the variance in the tax rates across different savings vehicles, rather than the level of taxes on savings in general. Moving to either a pure income or pure consumption tax is welfare improving in the results presented. This runs counter to the view that modern tax systems are already part way towards a consumption tax, and have already achieved the major portion of the potential gains available from a move to a pure consumption tax beginning from a pure income tax. 


\section{Bibliography}

Aaron, H. (1970) "Income Taxes and Housing", American Economic Review, 60, pp. 789-806.

Bacharach, M. (1970) Bi-Proportional Matrices and Input-Output Change. Cambridge University Press.

Ballard, C.L. and Goulder, L.H. "Tax Policy and Consumer Foresight: A General EQuilibrium Simulation Study". Paper presented for the Australian National University Conference on "Policy Use of Numerical Micro-Models: Issues, Applications, and New Developments" held in Canberra, Australia, August 22-24, 1983.

Boskin, M.J. (1978) "Taxation, Saving and the Rate of Interest", Journal of Political Economy, 63 (2), Part 2.

Caddy, V. (1976) "Empirical Estimation of the Elasticity of Substitution: A Review", mimeo, Industries Assistance Commission, Melbourne, Australia.

Feldstein, M. (1978) "The Rate of Return, Taxation and Personal Savings", The Economic Journal, Vol. 88 , No. 351, September, pp. 482-487.

Fullerton, D; Shoven, J.B. and Whalley, J. (1983) "Replacing the U.S. income tax with a progressive consumption tax: A sequences general equilibrium approach" Journal of Public Economics Vol. 20, pp. 3-22.

Harberger, A.C. (1962) "The Incidence of the Corporation Income Tax" Journal of Political Economy 70 (3) pp. 215-240.

Henry, K.R. (1983) "Distortions Due to the Nonrental Taxation of Capital in the Three Sector, Two Factor Model", mimeo, University of Canterbury.

King, M.A. (1983) "The Distribution of Gains and Losses from Changes in the Tax Treatment of Housing" in Behavioural simulation methods in tax policy analysis, M. Feldstein (ed) Chicago:University of Chicago Press.

Laidler, D. (1969) "Income Tax Incentives for Owner-Occupied Housing" in A.C. Harberger and M.J. Bailey (eds), The Taxation of Income from Capital, Brookings Institution, Studies of Government Finance, Washington, D.C.

Lewis,H.G. (1975) "Economics of time and 1abor supply" American Economic Review, Proceedings. 
Mansur, A.H. and Whalley, J. (1984) "Numerical Specification of Applled General Equilibrium Models: Estimation, Calibration, and Data", in H. Scarf and J. Shoven (eds) Applied General

Equilibrium Analysis, New York: Cambridge University Press.

Piggott, J. and Whalley, J. "Economic Effects of U.K. Tax-Subsidy Policies: A General Equilibrium Appraisal", Cambridge University Press, (forthcoming).

Rosen, H.S. (1979) "Housing Decistons and the c.S. Income Tax: An econometric analysis" Journal of Public Economics 11(1), pp, 1-23.

Sato, R. (1963) "Fiscal policy in a neoclassical growth model: An analysis of the time required for equilibrating adjustment", Review of Economic Studies, Vol. 30, pp. 16-23.

Shoven, J.B. and Whalley, J. (1972) "A General Equilibrium Calculation of the Effects of Differential Taxation of Income from Capital in the U.S." Journal of Public Economics, 1, pp. 281-321.

"Applied General Equilibrium Models of Taxation and International Trade" Journal of Economic Literature (forthcoming).

St Hilaire, F. and Whalley, J. (1983) "A Microconsistent Equilibrlum Data Set for Canada for Use in Tax Policy Analysis", The Review of Income and Wealth 29'(2), June, pp. 175-204. 
$8101 C$

$8102 \mathrm{C}$

$8103 C$

$8104 C$

$8105 \mathrm{C}$

$8106 C$

$8107 C$

8108C D S

8109 C DSJ

81100

81110

$8202 \mathrm{C}$

$8203 c$

$8204 C$

$8205 C$

82)

$8207 \mathrm{C}$

$8208 \mathrm{C}$

Markusen, James R. Factor Movements and Commodity Trade as Compliments: A Survey of some Cases.

Conlon, R.M. Comparison of Australian and Canadian Manufacturing Industries: Some Empirical Evidence.

Conlon, R.M. The Incidence of Transport Cost and Tariff Protection: Some Australian Evidence.

Laidler, David. On the Case for Gradualism.

Wirick, Ronald G. Rational Expectations and Rational Stabilization Policy in an Open Economy

Mansur, Ahsan and John Whalley Numerical quecification of Applied General Equilibrium Models: Estimation, Calibration, and Data.

Burgess, David F., Energy Prices, Capital Formation, and Potential GNP Jimenez, E. and Douglas H. Keare. Ibusing Consumption and Income in the Low Income Urban Setting: Estimates from Panel Data in El salvador

Whalley, John Labour Migration and the North-South Debate

Manning, Richard and John McMillan Government Expenditure and Comparative Advantage

Freid, Joel and Peter bowitt Why Inflation Reduces Real Interest Rates

1982

Manning, Richard and James R. Markusen Dynamic Non-Substitution and Long Run Production Possibilities

Feenstra, Robert and Ken Judd Tariffs, Technology Transfer, and Welfare Ronald W. Jones, and Douglas D. Purvis: International Differences in Response to Common External glocks: The Role of Purchasing Power Parity James A Brander and Barbara J. Spencer: Industrial Strategy with Committed Firms

Whalley, John, The North-South Debate and the Terms of Trade: An Applied General Equilibrium Approach

Roger Betancourt, Christopher Clague, Arvind Panagariya CAPI TAL UTI LI ZATI ON IN GENERAL EDUILIBRIUM

Mansur, Ahsan $\mathrm{H}$, On the Estimation of Import and Export Demand Elasticities and Elasticity Pessimism.

Whalley, J. and Randy Wigle PRICE AND QUANTITY RIGIDITIES IN ADJUSTMENT TO TRADE POLICY CHANGES: ALTERNATIVE FORMULATIONS AND INITIAL CALCULATIONS

\$209C DSU Jimehez, E. SQUATTING AND COMMUNITY ORGANIZATION IN DEVELOPING COUNTRIES: A CONCEPTUAL FRAMEWOKK 
$8210 \mathrm{C}$ Grossman, G.M. INTERNATIONAL COMPETITION AND THE UNIONIZED SECTOR

8211C Laidler,D. FRIEDMAN AND SCHWARTZ ON MONETARY TRENDS - A REVIEW ARTICLE

8212C Imam, M.H. and Whalley, J. INCIDENCE ANALYSIS OF A SECTOR SPECIFIC MINIMUM WACE IN A TWO SECTOR HARRIS-TODARO MODLL.

8213C Markusen, J.R. and Melvin, J.R. THE GAINS FROM TRADE THEOREM WITH INCREASING RETURNS TO SCALE.

8214C INDUSTRIAL ORGANIZATION AND THE GENERAL EQUILIBRIUM COSTS OF PROTECTION IN SMALL OPEN ECONOMIES.

S215C Laidler, D. DID MACROECONOMICS NEED TIIE RATIONAL EXPECTATIONS REVOLUTION?

$8216 \mathrm{C}$ Whalley, J. and Wigle, R. ARE DEVELOPED COUNTRY MULTILATERAL TARIFF REDUCTIONS NECESSARILY BENEFICIAL FOR THE U.S.?

8217C Bade, R. and Parkin, M. IS STERLING M3 THE RIGHT AGGREGATE?

8218C Kosch, B. FIXED PRICE EQUILIBRIA IN OPEN ECONOMIES.

\section{$\underline{1983}$}

3301C Kimbell, L.J. and Harrison, G.W. ON THE SOLUTION OF GENERAL EQUILIBRIUM MODELS .

$\therefore 302(:$ Melvin, J.R. A GENERAL EQUILIBRIUM ANALYSIS OF.CANADIAN OIL POLICY.

i3030: Markusen, J.R. and Svensson, L.F.O. TRADE IN COODS AND FACTORS WITH INTRERATIONAL DIFFERENCES IN TECHNOLOCY.

S30.4 Mohammad, S. Whalley, J. RENT SEEKINC IN INDIA: ITS COSTS AND POLICY SIGNIFICANCE.

8305C DSU Jimenez, E. TENURE SECURITY AND URBAN SỌUATTING.

8306C Parkin, M. WHAT CAN MACROECONOMIC THEORY TELL US ABOUT THE WAY DEFICITS SHOULD BE MEASURED.

3307C Parkin, M. THE INILATION DEBATE: AN ATTEMPT TO CLEAR THE AIR.

8308C. Wooton, I. LABOUR MIGRATION IN A MODEL OF NORTH-SOUIH TRADE.

×309C Deardorff, A.V. THE DIRECTIONS OF DEVELOPING COUNTRIES TRADE: EXAMPLES IROM PURE THEORY.

N3IOC Nanning, R. ADVANTAGEOUS REALLOCAIIONS AND MULTIPLE EOUULIBRIA: RESULTS FOR THE THREE-AGENT TRANSFER PROBI.EM. 
$8311 C$ DSU Mohammad, S. and Whalley, J. CONTROLS AND THE INTERSECTORAL TERMS OP TRADE IN INDIA.

$8312 C$ Brecher, Richard A. and Choudhr1, Ehsan U. NEW PRODUCTS AND THE FACTOR CONTENT OF INTERNATIONAL TRADE.

$8313 \mathrm{C}$ Jones, R.W., Neary, J.P. and Ruane, P.P. TWO-WAY CAPITAL FLOWS: CROSSHAULING IN A MODEL OF FOREIGN INVESTMENT.

$8314 C$ DSU Follain, J.R. Jr. and Jimenez, E. THE DEMAND FOR HOUSING CHARACTERISTICS IN DEVELOPING COUNTRIES.

$8315 C$ Shoven, J.B. and Whalley, J. APPLIED GENERAL EQUILIBRIUM MODELS OF TAXATION AND INTERNATIONAL TRADE.

$8316 \mathrm{C}$ Boothe, Paul and Longworth David. SOME IRREGULAR REGULARITIES IN THE CANADIAN/U.S. EXCHANGE MARKET.

$8317 \mathrm{CHamilton,} \mathrm{Bob} \mathrm{and} \mathrm{Whalley,} \mathrm{John.} \mathrm{BORDER} \mathrm{TAX} \mathrm{ADJUSTMENTS} \mathrm{AND} \mathrm{U.S.} \mathrm{TRADE.}$

$8318 \mathrm{C}$ Neary, J. Peter, and Schweinberger, Albert G. FACTOR CONTENT FUNCTIONS AND THE THEORY OF INTERNATIONAL TRADE.

8319C Veall, Michael R. THE EXPENDITURE TAX AND PROGRESSIVITY.

$8320 \mathrm{C}$ Melvin, James R. DOMESTIC EXCHANGE, TRANSPORTATION COSTS AND INTERNATIONAL TRADE.

8321C Hamilton, Bob and Whalley, John. GEOGRAPHICALLY DISCRIMINATORY TRADE ARRANGEMENTS.

$8322 \mathrm{C}$ Bale, Harvey Jr. INVESTMENT FRICTIONS AND OPPORTUNITIES IN BILATERAL U.S.-CANADIAN TRADE RELATIONS.

8323C Wonnacott, R.J. CANADA-U.S. ECONOMIC RELATIONS--A CANADIAN VIEW.

$8324 \mathrm{C}$ Stern, Robert M. U.S.-CANADIAN TRADE AND INVESTMENT FRICTIONS: THE U.S. VIEW.

8325C Harrison, Glenn, H. and Kimbell, Larry, J. HOW ROBUST IS NUMERICAL GENERAL EQUILIBRIUM ANALYSIS?

8326C Wonnacott, R.J. THE TASK FORCE PROPOSAL ON AUTO CONTENT: WOULD THIS SIMPLY EXTEND THE AUTO PACT, OR PUT IT AT SERIOUS RISK?

8327C Bradford, James C. CANADIAN DEFENCE TRADE WITH THE U.S. Conklin, David. SUBSIDY PACTS.

Rugman, Alan M. THE BEHAVIOUR OF U.S. SUBSIDARIES IN CANADA:

IMPLICATIONS FOR TRADE AND INVESTMENTS. 
8328C Boyer, Kenneth D. U.S.-CANADIAN TRANSPORTATION ISSUES.

$8329 \mathrm{C}$ Bird, Richard M. and Brean, Donald J.S. CANADA-U.S. TAX RELATIONS: ISSUES AND PERSPECTIVES.

8330C Moroz, Andrew R. CANADA-UNITED STATES AUTOMOTIVE TRADE AND TRADE POLICY ISSUES.

8331C Grey, Rodney de C. and Curtis, John. INSTITUTIONAL ARRANGEMENTS FOR U.S.-CANADIAN NEGOTIATIONS. PART I: CANADA-U.S. TRADE AND ECONOMIC ISSUES: DO WE NEED A NEW INSTITUTION? PART II: INSTITUTIONAL ARRANGEMENTS FOR MANAGING THE CANADA-U.S. ECONOMIC RELATIONSHIP.

1984

$8401 \mathrm{C}$ Harrison, Glenn $W$. and Manning, Richard. BEST APPROXIMATE AGGREGATION OF INPUT-OUTPUT SYSTEMS.

8402C Parkin, Michael. CORE INFLATION: A REVIEW ESSAY.

8403C Blomqvist, Ảke, and McMahon, Gary. SIMULATING COMMERICAL POLICY IN A SMALL, OPEN DUAL ECONOMY WITH URBAN UNEMPLOYMENT: A GENERAL EQUILIBRIUM APPROACH.

8404C Wonnacott, Ronald. THE THEORY OF TRADE DISCRIMINATION: THE MIRROR IMAGE OF VINERIAN PREFERENCE THEORY?

8405C Whalley, John. IMPACTS OF A 50\% TARIFF REDUCTION IN AN EIGHT-REGION GLOBAL TRADE MODEL.

8406C Harrison, Glenn W. A GENERAL EQUILIBRIUM ANALYSIS OF TARIF? REDUCTIONS.

8407C Horstmann, Ignatius and Markusen, James R. STRATEGIC INVESTMENTS AND THE DEVELOPMENT OF MULTINATIONALS.

8408C Gregory, Allan W. and McCurdy, Thomas H. TESTING THE UNBIASEDNESS HYPOTHESIS IN THE FORWARD FOREIGN EXCHANGE MARKET: A SPECIFICATION ANALYSIS .

8409C Jones, Ronald $\mathrm{H}$. and Kierzkowski, Henryk. NEIGHBORHOOD PRODUCTION STRUCTURES WITH APPLICATIONS TO THE THEORY OF INTERNATIONAL TRADE.

8410C Weller, Paul and Yano, Makoto. THE ROLE OF FUTURES MARKETS IN INTERNATIONAL TRADE: A GENERAL EỌUILIBRIUM APPROACH.

8411C Brecher, Richard A. and Bhagwati, Jagdish N. VOLUNTARY EXPORT RESTRICTIONS VERSUS IMPORT RESTRICTIONS: A WELFARE-THEORETIC COMPARISON. 
8412C Ethier, Wilfred J. ILLEGAL IMMIGRATION.

8413C Eaton, Jonathon and Gene M. Grossman. OPTIMAL TRADE AND INDUSTRIAL POLICY UNDER OLIGOPOLY.

8414C Wooton, Ian. PREFERENTIAL TRADING AGREEMENTS - A 3xn MODEL.

8415C Parkin, Michael. DISCRIMINATIN, BETWEEN KEYNESIAN AND

CLASSICAL THEORIES OF THE BUSINESS CYCLE; JAPAN 1967-1982

8416C Deardorff, Alan V. FIRless FIRwoes: HOW PREFERENCES CAN INTERFERE WITH THE THEOREMS OF INTERNATIONAL TRADE.

8417C Greenwood, Jeremy. NONTRADED GOODS, THE TRADE BALANCE, AND THE BALANCE OF PAYMENTS.

8418C Blomqvist, Ake and Sharif Mohammad. CONTROLS, CORRUPTION, AND COMPETITIVE RENT-SEEKING IN LDCS.

8419C Grossman, Herschel I. POLICY, RATIONAL EXPECTATIONS, AND POSITIVE ECONOMIC ANALYSIS.

8420C Garber, Peter M. and Robert G. King. DEEP STRUCTURAL EXCAVATION? A CRITIOUE OF EULER EQUATION METHODS.

8421C Barro, Robert J. THE BEHAVIOR OF U.S. DEFICITS.

8422C Persson, Torsten and Lars E.0. Svensson. INTERNATIONAL BORROWING AND TIME-CONSISTENT FISCAL POLICY.

8423C Obstfeld Maurice. CAPITAL CONTROLS, THE DUAL EXCHANGE RATE, AND DEVALUATION.

8424C Kuhn, Peter. UNION PRODUCTIVITY EFFECTS AND ECONOMIC EFFICIENCY.

8425C Hamilton, Bob and John Whalley. TAX TREATMENT OF HOUSING IN A DYNAMIC SEOQUENCED GENERAL EOUUILIBRIUM MODEL.

8426C Hamilton, Bob, Sharif Mohammad, and John whalley. RENT SEEKING AND THE NORTH-SOUTH TERMS OF TRADE. 